\title{
High Order Thinking Ability Through Social Studies Problem-Based Learning at a Junior Secondary School in Eastern Java
}

\author{
E. Triasningsih*, Laurens Kaluge, Sudiyono \\ Graduate Program of Social Studies Education \\ Universitas Kanjuruhan Malang \\ Malang, Indonesia \\ *emyhyuno84@gmail.com
}

\begin{abstract}
The purpose of this study was an attempt to examine the differences between problem based learning and traditional teaching methods in order to perform high thinking skills and motivation among students in learning social studies. This quantitative study randomly sampled 60 students at a Junior Secondary School. Data were collected by using tests for thinking ability, observations on teaching methods and documentation for having learning achievement in social studies. The statistical analysis discovered three main findings. First, in terms of pretest, the experimental and control groups were equal, there was no significant difference. Second, there was a significant difference in high thinking ability between students taught by problem based and conventional methods. Third, the high thinking ability was significantly affecting the of learning motivation of students. For social studies, high thinking ability and learning motivation were positively correlated.
\end{abstract}

Keywords-teaching methods, high thinking skills, learning motivation, social studies

\section{INTRODUCTION}

The results of studies conducted at Junior Secondary Schools in Probolinggo Regency, part of East Java, showed that in teaching the social studies, teachers used conventional methods so that students could not able to think at high levels [1-3]. This was due to the teaching methods by the teachers did not encourage the students' learning motivation. Learning in the classroom so far had only been teacher-centered and was generally carried out using conventional methods through lecturing and memorizing so that students were less motivated to think harder. Therefore, changes were needed in teaching and learning methods, one of which was the problem-based learning (PBL) method.

Problem-based learning was different from other learning models. In this learning model, the teacher poses various problems to students, asks questions, and facilitates investigation and dialogue. The teacher provides the opportunity for students to determine the topic of the problem to be discussed, even though the teacher had actually determined what problem topics should be discussed. The main thing was that the teacher provides a supporting framework that could improve the ability to explore and think hard. The learning process was directed so that students were able to solve problems systematically and logically. PBL presupposes the creation of an open and honest classroom environment, because the classroom itself was a place for students to exchange ideas in response to various problems. Thus problembased learning improves students' thinking skills because it trains students to authentically solve daily problems [4].

The PBL learning method was learning that was intended to develop students' learning motivation, encourage students to be able to think at higher levels, encourage students to optimize their metacognitive abilities, and become meaningful learning so as to encourage students to have high self-confidence and be able to learn independently [5].

A study conducted by Putri, Corebima, and Mahanal [6] concluded that there was no influence between problem-based learning strategies on the metacognitive skills of students with low academic abilities. Apart from using the PBL learning method to train high order thinking skills (HOTS), motivation was needed in learning because it could encourage students to carry out learning activities. Learning motivation was something that encouraged, moved and directed students in learning [7]. Motivation was an incentive for students to arouse and direct students to learn something new. This was in accordance with Aryani's study [8] which concluded that the learning motivation of students was higher in the PBL type of learning model. But this was not in accordance with the results of research by Astuti and Sudarisman [9] which concluded that there was no significant effect between scientific attitudes and student motivation on cognitive, affective, and psychomotor achievement.

In fact, there were still many students who did not able to think HOTS. Even though the questions reflected high-level thinking, were used by the teacher repeatedly so that they were degraded to a lower level. With the habit of solving problems, 
it was hypothesized that student learning motivation will increase. In addition, conventional teacher-centered learning tended to repeat so that students experienced degradation of thinking and demystifying memory only.

\section{METHODS}

This study used a quasi-experimental design. This research was a quasi experiment with the design of "The Non equivalent Pretest-posttest Control Group Design" [10]. The research was started by pretest and ended by posttest in both groups, namely experimental and control. Treatment in the experimental group was problem-based learning, while in the control group it was conventional instruction. In the last stage, the posttest score was associated with learning motivation.

The location of this study was randomly selected at SMPN 3 Tiris, Tiris District, which represented the schools in the regency of Probolinggo because had no extreme characteristics of classes, students, teachers, and environment. Two parallel class clusters were taken randomly into samples. The number of students involved was 60 people for two equally large groups. The two parallel study groups were considered as the experimental group and the control group. Furthermore, the two groups underwent different treatments. The experimental class was treated with the PBL method and the control class was treated using conventional methods. Then the study ended up with testing the causal relationship between HOTS and learning motivation.

The independent variable in this study was learning (problem-based versus conventional). While the dependent variable was higher order thinking skills in social achievement studies. Three research instruments were used in this study, namely a pretest on initial ability in social studies, a posttest on HOTS in social studies and a scale that measures learning motivation.

Data were taken before and after treatment, namely at the end of the lesson. Pretest data were the values of critical thinking skills. The final posttest data were still in the form of critical thinking skills. The research data concerning the effect of problem-based learning on learning motivation and critical thinking skills of students.

Data were analyzed statistically. The utilized analyses were descriptive statistics and t-test for the hypothesis testing with the significance level of $0.5 \%$.

\section{RESULTS AND DISCUSSION}

The data of the pretest on social studies were analyzed to determine the prior situation of the students' initial abilities. The pretest score of the experimental class was 63.94 with a standard deviation of 12.22. And the pre-test average of the control class was 60.12 with a standard deviation of 14.35 . The difference between the two groups was indicated by the t-test of 1.54 which means it was not significant. Thus it was no significant difference between the experimental and control groups. This finding illustrated that both groups were equivalent and proper to continue with the treatment [10] as previously mentioned.

After the experimental action, a posttest was carried out. In the experimental group the PBL method was used, and the control class applied the conventional method. The mean score of the experimental group was 74.46 with a standard deviation of 8.09. While the mean score of the control class was 70.71 with a standard deviation of 7.22. It could be seen that the average value of the experimental class was higher than the average value of the control class. The difference between the two posttest scores was significant as indicated by the t-test of $2.03(\mathrm{p}<0.01)$. These findings implied that the average thinking score of HOTS experimental class was better than the control group because it uses the PBL method. In other words, the use of conventional teacher-centered methods was ineffective in increasing student HOTS.

From the finding, it was clear that the control class underperformed the experimental group in HOTS. This could be seen from the increase in the average value of HOTS in the experimental class compared to the average value of the control class, as the effect of PBL application. The findings of this study were in accordance with the studies of Aryani [8], Fatimah [11], Herzon, Budijanto, Utomo [12], Jayanti [13], Marlina, Utaya, Yuliati [14], and Royantoro [2] which showed that the PBL learning model had a significant effect on the HOTS of students. However, the same results of this study were not in line with the research of Putri, Corebima, Mahanal [6] who concluded that there was no influence between PBL learning strategies on metacognitive skills of students with low academic abilities. Based on the data analysis as described above, it was concluded that students must be taught through effective learning methods to use HOTS in solving a problem and be able to find solutions to these problems independently.

The results showed that there was a positive influence of HOTS on students' learning motivation. The $t$ count value of 3.103 reflected a significance of 0.003 . In other words, there was a significant positive effect of HOTS ability on students' learning motivation. The magnitude of the effect could be seen from the gain score in the experimental class 0.39 (moderate) and 0.08 (low) in the control class. Thus it was said that "there was a difference in HOTS thinking skills between students who have high and low motivation." The result of this study was in accordance with study carried out by Wahid [3] which showed an increase in the ability of students who learn with high motivation. This also supported the opinion expressed by Dimyati and Mudjiono [15] that motivation was seen as a mental drive which mentions the mental strength that drives learning as learning motivation. Based on the data described, it may be stated that learning motivation was very important for students. The learning motivation made students to study hard and had a desire to advance in students and could improve HOTS.

The students who learnt with the PBL approach were not only superior in HOTS than those who used conventional methods $(p<0.05)$, but also in learning motivation. The effect 
of the PBL method had an impact on HOTS thinking levels and then the student learning motivation. These results supported the study of Hobri, Septiawati, Prihandoko [16], Irmawati, Supriyati, and Suseno [17], Insyasiska, Zubaidah, Susilo [18] which showed that the learning strategies and motivation chosen had a positive effect in increasing reciprocally the HOTS of students. The results of this study indicated that the learning method used had an effect on HOTS and student motivation in social studies lessons.

\section{CONCLUSION}

It was concluded that there was a significant effect of PBL, HOTS and learning motivation of social studies. The more frequent use of the PBL, the higher the ability of higher order thinking would be. That was the power of using the PBL in order to improve the student learning for social studies at school.

\section{REFERENCES}

[1] E.L. Palupi and A.B. Kusuma, "Penguatan pendidikan karakter pada matematika berbasis higher order thinking skill (HOTS)," Unpublished, 2019.

[2] F. Royantoro, "Pengaruh model pembelajaran problem based learning terhadap higher order thinking skills peserta didik," Berkala ilmiah, vol. 6, no. 3, pp. 15-17, 2018.

[3] A.H. Wahid and R.A. Karimah., "Integrasi Higher Order Thinking Skill (HOTS) dengan Model Creative Problem Solving," Modeling - Jurnal program studi PGMI, vol. 5, no. 1, pp. 82-98, 2018.

[4] R.I. Arends, Learning to teach. New York: McGraw Hill, 2020.

[5] S. Abidin, "Pengaruh pemanfaatan perpustakaan sekolah terhadap prestasi belajar peserta didik di SMK Pratidina Makassar," Jurnal Diskursus Islam, vol. 6, no. 1, pp. 12-25, 2018.

[6] N.A. Putri, A.D. Corebima, and S. Mahanal, "Pengaruh Strategi Pembelajaran (Pbl Dan Rt) Terhadap Keterampilan Metakognitif, Hasil Belajar Biologi, Dan Retensi Siswa Berkemampuan Akademik Rendah Kelas X Pada SMA,” Unpublished, 2013.
[7] S.E. Astuti, and Resminingsih, Bahan dasar untuk pelayanan konseling pada satuan pendidikan menengah. Jakarta: Grasindo, 2010.

[8] D. Aryani, "Efektivitas model pembelajaran problem based learning (PBL) dan problem solving (PS) untuk meningkatkan berpikir kritis dengan memperhatikan motivasi berprestasi siswa pada mata pelajaran ekonomi kelas IX SMA Negei 6 Bandar Lampung," Unpublished Master Theses, Lampung: Universitas Lampung, 2016.

[9] S. Astuti, W., and S. Sudarisman, "Pembelajaran IPA dengan Pendekatan Keterampilan Proses Sains Menggunakan Metode Eksperimen Bebas Termodifikasi Dan Eksperimen Terbimbing Ditinjau Dari Sikap Ilmiah Dan Motivasi Belajar Siswa," Jurnal Inkuiri, vol. 1, no. 1, pp. 51-59, 2012.

[10] J.R. Fraenkel and N.E. Wallen, How to Design and Evaluate Research in Education. New York: McGraw-Hill, 2018.

[11] I.D. Fatimah, "Penerapan model pembelajaran make a match dengan media kartu bergambar untuk meningkatkan motivasi dan hasil belajar siswa," Ilmu pendidikan, vol. 2, no. 1, pp. 28-37, 2017.

[12] H.H. Herzon, Budijanto, and D.H. Utomo, "Pengaruh problem-based learning (PBL) terhadap keterampilan berpikir kritis," Jurnal pendidikan, vol. 3 , no. 1, pp. 42-46, 2018.

[13] R.D. Jayanti, Romlah, and A. Saregar, "Efektivitas pembelajaran fisika model problem based learning (PBL) melalui metode POE terhadap kemampuan berpikir tigkat tinggi peserta didik," in Seminar Nasional Pendidikan -Program Studi Pendidikan Fisika, Bandarlampung $28 \mathrm{Mei}$ 2016, pp. 208-214.

[14] Marlina, S. Utaya, and L. Yuliati, "Pengaruh authentic problem based learning (aPBL) terhadap penguasaan konsep IPA siswa kelas IV Sekolah Dasar," Jurnal Pendidikan, vol. 2, no. 11, pp. 1509-1514, 2017.

[15] M. Dimyati, Belajar dan pembelajaran. Jakarta: Rineka Cipta, 2009.

[16] Hobri, I. Septiawati, and A.C. Prihandoko, "High-order thinking skill in contextual teaching and learning of mathematics based on lesson study for learning community," International journal of engeneering \& technology, vol. 7, no. 3, pp. 1576-1580, 2018.

[17] S. Irmawati and M. Suseno, "Pengaruh strategi pembelajaran dan motivasi belajar terhadap higher order thinking skills (HOTS) dalam pembelajaran IPA peserta didik kelas IV sekolah dasar," Unpublished, 2018.

[18] D. Insyasiska, S. Zubaidah, and H. Susilo, "Pengaruh project based learning terhadap motivasi belajar, kreativitas, kemampuan berpikir kritis, dan kemampuan kognitif siswa pada pembelajaran biologi," Jurnal pendidikan biologi, vol. 7, no. 1, pp. 9-21, 2015. 